\title{
Strateginė Europos Sajungos saugumo ir gynybos autonomija
}

\begin{abstract}
Šiame straipsnyje pristatomi teoriniai svarstymai dèl strateginès autonomijos suvokimo saugumo ir gynybos srityje. Jis pradedamas nuo termino „autonomija“ ir ES su autonomija siejamų dilemų aptarimo. Po to įvardijamos ir aprašomos pagrindinès iniciatyvos saugumo ir gynybos srityje, kurios lemia ES strateginès autonomijos siekį joje, ir jų igyvendinimo problemos. Pristatomos išvados pagrịstos kokybine šaltinių analize, iš esmès susitelkiant $\mathfrak{i}$ ES norminius dokumentus. Ši analizė leido suformuluoti šias išvadas. Pirma, ES norminiuose dokumentuose nèra aiškaus „strateginès autonomijos" apibréžimo ir jos aiškinimo. Tai lemia skirtingus vertinimus ar net nesusipratimus tarp valstybių narių, nes jos gali skirtingai suvokti strateginę autonomiją, ypač saugumo ir gynybos srityje. Antra, vis dèlto dauguma valstybių narių pripažịsta, kad saugumo ir gynybos srityje galima pasiekti strateginę autonomiją. Tačiau kol kas valstybès narès skirtingai ją suvokia. Išsiskiria du ES valstybių narių deklaruojami požiūriai: visiškas suverenitetas arba lanksti autonomija. Trečia, pastaruosius kelerius metus ES vykdytos saugumo ir gynybos iniciatyvos turi potencialo tapti strateginés autonomijos siekio pagrindu.
\end{abstract}

\section{Ivadas}

Per pastaruosius kelerius metus Europos saugumo aplinka pastebimai pablogejo. Terorizmas, nelegali migracija, žlugusios valstybès ir pilietiniai karai pietuose padidino grèsmes europiečių saugumui. İtampa santykiuose su Rusija dèl Krymo statuso ir Rytų Ukrainos teritorijos taip pat kelia rimtų iššūkių taikai ir stabilumui Europoje. Be to, nežinomybė dẻl Jungtinių Amerikos Valstiju ísipareigojimų Europos saugumo atžvilgiu, atsiradusi Donaldo Trumpo prezidento kadencijos laikotarpiu, taip pat regioninè Azijos ir Vidurinių Rytų įtakos konkurencija rodo neramią aplinką aplink Europą. Atsižvelgiant i šiuos ịvykius, aktualejja Europos Sąjungos (ES) saugumo ir gynybos klausimas.

\footnotetext{
"Plk., habil. dr. Tadeusz Zieliński - Karo meno akademijos (Varšuva, Lenkija) profesorius. Adresas korespondencijai: al. gen. A. Chruściela „Montera“ 103, 00-910, Warszawa, Poland; tel. +48-261-813-431; el. p. t-zielinski@akademia.mil.pl 
Raginimai artimiau bendradarbiauti ES gynybos srityje, „Europos strateginès autonomijos" ar realios „Europos kariuomenès" kūrimas yra tik keletas iniciatyvų, siekiant skatinti bendrą saugumo ir gynybos politiką (BSGP, angl. CSDP). Be to, tai nèra tik tušti žodžiai, nes juos patvirtina konkretūs veiksmai ir iniciatyvos. $2016 \mathrm{~m}$. vasarą pristatyta Europos Sąjungos visuotinė užsienio ir saugumo politikos strategija (ESPS, angl. EUGS), bendrais bruožais apibūdinanti ES užsienio ir saugumo politikos strategiją, buvo pirmasis tokio pobūdžio dokumentas per trylika metų. $2016 \mathrm{~m}$. liepą paskelbta naujoji ES ir NATO bendra deklaracija, siekiant plèsti bendradarbiavimą daugelyje bendrų su saugumu ir gynyba susijusių sričių. Per pirmajj preliminarų ESPS igyvendinimo etapą, $2016 \mathrm{~m}$. lapkritị, Taryba prième išvadas dèl jos iggyvendinimo saugumo ir gynybos srityje, kurias Europos Taryba patvirtino gruodi vykusio aukščiausio lygio susitikimo metu.

Dèl šių sprendimų, remiantis Lisabonos sutartimi, pradètas nuolatinis struktūruotas bendradarbiavimas (NSB, angl. PESCO), atliekant kasmetes peržiūras ir stiprinant ES kovos grupes. Tuo pat metu Komisija pristate Europos gynybos veiksmų planą, taip siekdama pagreitinti Europos gynybos tikslų finansavimą, dèl kurio $2017 \mathrm{~m}$. birželį buvo ịsteigtas Europos gynybos fondas. Be to, vyriausioji igaliotine Federica Mogherini 2017 m. birželị pristate Europos gynybos ateití, kaip Europos ateities baltosios knygos dalį.

$2016 \mathrm{~m}$. birželị vyriausioji igaliotinė užsienio reikalams ir saugumo politikai, pristatydama ESPS Europos Tarybai, pristatè ir strateginès autonomijos koncepciją. Šio dokumento, ịskaitant ES išorinių veiksmų gaires, tikslas yra pasiekti „tinkamą“ strateginès autonomijos „lygi “ gynybos ir saugumo srityje. ESPS išlieka gana neapibrèžta, jei ne dviprasmiška, šios koncepcijos turinio ir svarbos atžvilgiu. Europos strateginei autonomijai stinga bendro apibrěžimo, ir tai gali būti pagrindinè koncepcijos ịgyvendinimo kliūtis. Be to, po „Brexito“ Prancūzija ir Vokietija tampa pagrindinèmis ES veikejjomis, tačiau jų požiūris gynybos ir saugumo klausimais skiriasi. Mažesnès valstybės narès taip pat skirtingai vertina Europos strateginę autonomiją. Europos politikai pradėjo kartoti strateginès autonomijos terminą per diskusijas dèl ịvairių ES funkcijų, atkreipdami dèmesị $\mathfrak{i}$ tai, kad ES derètų stengtis pasiekti strateginę autonomiją. Vis dèlto nèra tikslaus ir aiškaus apibrèžimo, ką reiškia strateginè autonomija. Viena sričių, kurią Europos Komisijos atstovai nurodè kaip sritị, kurioje ES derètų siekti strateginès autonomijos, yra saugumas ir gynyba. Vis dèlto gynybos ir saugumo sritis tradiciškai ir pirmiausia yra vertinama kaip valstybès narès prerogatyva, dèl to valstybių narių vizijos dèl strateginès autonomijos pasiekimo gali skirtis. Kita vertus, neseniai pristatytos priemonès gali padèti rasti 
labai reikalingą kompromisą ir palengvinti galimą supanašejimą BSGP srityje.

Vertinant ambicingus valstybių narių NSB, taip pat ES ir NATO bendradarbiavimo planus bei papildomas priemones, siekiant užtikrinti realią ES pajègumų, vystomų pagal jų plètojimo planą (PPP, angl. CDP) ir vykdant suderintą metinę peržiūrą gynybos srityje (SMPGS, angl. CARD), plètrą, reikia iškelti svarbiausius klausimus, susijusius su ES ateitimi saugumo ir gynybos srityje strateginės autonomijos atžvilgiu. Pirmiausia, kaip yra suprantama strateginè autonomija saugumo ir gynybos srityje ir ar tai atsispindi ES dokumentuose? Antra, kokie veiksmai, kurių imamasi ES saugumo ir gynybos srityje, suteikia galimybę pasiekti strateginę autonomiją? Darbe bus bandoma atsakyti it šiuos klausimus.

Pradinis taškas, vertinant ES strateginę autonomiją saugumo ir gynybos srityje, buvo kokybinè turimos literatūros analizè. Pirmoji literatūros grupè apėmé literatūrą, susijusią su terminu , autonomija“, antroji grupè - norminius dokumentus, susijusius su saugumo ir gynybos sritimi ES. Trečią grupę sudaro straipsniai, tyrimų institutų ir ekspertų grupių tyrimų, susijusių su ES klausimais, ịskaitant saugumo ir gynybos srities tyrimus strateginès autonomijos kontekste, medžiaga.

Pirmajame skyriuje pristatoma teorija, susijusi su strategine autonomija ìvairiose srityse. Vis dèlto jame taip pat siūlomas aiškus apibrèžimas, susijęs su saugumo ir gynybos sritimi. Antrajame skyriuje nagrinèjamos dèl ES saugumo ir gynybos strateginès autonomijos kylančios dilemos, t. y. kaip daugelis ES veikèjų suvokia strateginę autonomiją. Trečiajame skyriuje pristatomos pagrindinès ES stiprinimo iniciatyvos, siekiant strateginès autonomijos saugumo ir gynybos srityje.

\section{Autonomijos koncepcija - teorija}

Ruthos Lapidothos siūlomas klasikinis modelis apima keturias autonomijos apibrèžimo kategorijas. Pirmoji aiškina autonomiją kaip teisę tam tikru mastu elgtis laisvai. Antroji kategorija yra susijusi su autonomijos, kaip didesnio ar mažesnio masto nepriklausomybès sinonimo, pripažinimu. Trečioji kategorija apima apibréžimus, prilyginančius autonomiją decentralizacijai, ketvirtoji kategorija - apibrěžimus, kuriuose pabrěžiama, kad autonominè visuomenè turi išskirtines ịstatymų leidybos, administracines ir teismines teises konkrečiais klausimais ${ }^{1}$.

\footnotetext{
${ }^{1}$ Lapidoth, R. (1997), Autonomy. Flexible Solutions to Ethnic Conflicts, Washington: United States Institute of Peace Press, p. 33.
} 
Terminas „autonomija“ yra kilęs iš graikų kalbos žodžio autónomos, reiškiančio savivaldos, nepriklausomybès turèjimą. Jo etimologinę kilmę nusako du žodžiai: autós, reiškiantis savarankiškumą, ir nomós, reiškiantis paprotị, ịstatymą ir principą. Iš pradžių autonomija reiške galimybę savarankiškai spręsti tam tikrus klausimus. Šiandien ji apima tokius elementus kaip „nepriklausomybė, reiškinių, subjektų nepriklausomybe, dažnai pripažǐstama kitų reiškinių, subjektų atžvilgiu ir reiškianti jų atskirumą arba jų savarankišką funkciją visuomenejje“. Kaip nurodo Heinrichas Oberreuteras, autonomija tai galimybė savarankiškai spręsti pagal galiojančias teisines nuostatas ${ }^{2}$. Savo ruožtu Henry'is J. Steineris apibrežia autonominius režimus kaip vyriausybines sistemas ar posistemes, kurias administruoja ar valdo etninès mažumos arba jų nariai ${ }^{3}$, o Janas-Erikas Lane’as ir Svante’as Erssonas nurodo, kad autonomija gali būti taikoma nustatant ir federacines valstybes sudarančias dalis, ir vienos valstybès regionus ${ }^{4}$.

Nepaisant gausios lyginamosios medžiagos ir didejjančio autonomijos tyrimų skaičiaus, vis dar pasigendama visuotinai pripažịstamo autonomijos apibrèžimo, o pati koncepcija išlieka miglota. Gnanapala Welhengama pateikia vaizdingą pavyzdį ir lygina autonomiją su juoda kate tamsiame kambaryje, kurios nors ir nematome, pagal judesius galime daryti išvadą, kad ji ten $\mathrm{yra}^{5}$. Tą pati galima pasakyti ir apie autonomiją - koncepcija yra ịtraukta ị tarptautinius dokumentus (tokius kaip Europos visuotine strategija), tačiau tikslus jos apibrěžimas ir tiksli jos reikšmès specifikacija neatrodo įmanomi. Valstybès nenoriai vartoja šị terminą, baimindamosi, kad vien jo vartojimas gali būti aiškinamas kaip netiesioginis teisés ị autonomiją pripažinimas.

Taip pat nesutariama dèl autonomijos tipologijos, o nauji tyrimo metodai (ịskaitant Tkaciko, Iwaneko) vis dar konkuruoja su „klasikiniais“ metodais (iskaitant Lapidothos ir Hannumo). ${ }^{6}$ Taip yra dèl to, kad autonomija yra sisteminis sprendimas, išplètotas didesniu mastu, remiantis daugiau praktika ir teisiniais sprendimais nei teoriniais modeliais ${ }^{7}$. Literatūroje išskiriama daug autonomijos tipologijų, kurios kartais yra net prieštaringos. Tyrejjai taiko skir-

\footnotetext{
${ }^{2}$ Oberreuter, H. (1995), “Autonomie”, In Staatslexikon, Vol. 1, Freiburg, Basel, Vienna: Herder, p. 491.

${ }^{3}$ Steiner, H.J. (1991), "Ideas and Counter-Ideas in the Struggle over Autonomy Regimes for Minorities", Notre Dame Law Review, 5 (66), p. 1561.

${ }^{4}$ Lane, J.-E., Ersson, S. (1994), Politics and Society in Western Europe. London: Sage Publications, p. 219.

${ }^{5}$ Welhengama, G. (1999), "The Legitimacy of Minorities. Claim for Autonomy through the Right to SelfDetermination”, Nordic Journal of International Law, 4 (68), p. 425.

${ }^{6}$ Hannum, H., Lillich R. B. (1980), “The Concept of Autonomy in International Law”, American Journal of International Law, 4 (74), pp. 858-889.

${ }^{7}$ Iwanek, J. (2014), "Pojęcie autonomii terytorialnej we współczesnej europejskiej przestrzeni demokratycznej” in Domagała, M., Iwanek, J. (eds.), Autonomia terytorialna w perspektywie europejskiej. Tom I: Teoria - historia, Toruń: Wydawnictwo Adam Marszałek, p. 5.
} 
tingus kriterijus: dèl sprendimo naudos gavèjų, dèl autonomijos tikslo arba dèl autonominio vieneto ir valstybès, kurios dalis jis yra, santykių. Tkacikas išskiria penkis autonomijos laipsnius: nuo asmeninès iki kultūrinès, nuo funkcinès ir administracinès iki ịstatyminès. Kiekvienam paskesniam lygiui priskiriama daugiau galių nei ankstesniam. Tyrejas atskiria asmeninę autonomiją nuo kultūrinès. Pirmąją jis traktuoja kaip garantiją gerbti pagrindines asmens, kuris nebūtinai yra konkrečios grupès narys, teises (dažniausiai pilietines). O kultūrinè autonomija yra sąmoningas taikomų ịstatymų išplètimas, juos taikant konkrečiai kalbai ar kultūros grupei. Dèl to kultūrinè autonomija yra susijusi su bendruomene ir su asmenų suvokiama bendruomenès narių asmenine autonomija ${ }^{8}$. Benedikteras nesutinka su šiuo metodu ir nurodo, kad autonominiai sprendimai turètų būti orientuoti ị grupę, nes subjektas yra bendruomené $\dot{ }^{9}$.

Tkacikas apibrèžia funkcinę autonomiją kaip vienos aiškiai ribotos viešosios veiklos srities, pavyzdžiui, kalbos politikos viename mokyklų rajone, kontrolès decentralizavimo procesą, o administracinę autonomiją kaip visą tokių funkcinių autonomijų (pvz., dèl mokyklų, teismų, religijos, viešųų paslaugų) grupę ${ }^{10}$. Praktiškai tai reiškia, kad autonominei bendruomenei suteikiama daugybè igaliojimų. Leidimai gali būti susiję su svarbiausiais tikslais arba ne. Korsika būtų klasikinis administracinès autonomijos pavyzdys. Vis dèlto kai kurie autoriai atmeta tokị skirstymą ir traktuoja funkcinę autonomiją geriausiu atveju kaip kultūrinès ar administracinės autonomijos subkategoriją, dažnai nurodo Suomijos reglamentus dẻl švedų mažumos (išskyrus Alandų salas) kaip specialų kalbos reglamentavimo ịgyvendinimą, o ne kaip atskirą autonomijos formą ${ }^{11}$. Pats Tkacikas priskiria švediškai kalbančių Suomijos gyventojų dalị tam tikrai pilkajai savo kuriamos tipologijos zonai ${ }^{12}$.

Tkaciko (2008) tipologinio modelio viršuje yra įstatymų leidybos autonomija, kuri skiriasi nuo administracinès autonomijos priskiriamų igaliojimų mastu ir apimtimi. Funkciné autonomija taip pat siejama su igaliojimų priskyrimu, tačiau, kitaip nei įstatymų leidybos autonomija, ji nesuteikia įstatymų leidybos igaliojimų, t. y. tam nereikia steigti ịstatymų leidybos institucijų, kurios kurtų atitinkamai bendruomenei taikytinus ịstatymus. Papildomas skiriamasis elementas yra daugumos įstatymų leidybos autonomijų geografinis ats-

\footnotetext{
${ }^{8}$ Tkacik, M. (2008), “Characteristic of Forms of Autonomy”, International Journal on Minority \& Group Rights, 2/3(15), p. 371.

${ }^{9}$ Benedikter, T. (2009), The World's Modern Autonomy Systems. Concepts and Experiences of Regional Territorial Autonomy, Bolzano: Eurac, p. 40.

${ }^{10}$ Tkacik, M. (2008), op. cit., p. 380.

${ }^{11}$ Benedikter, T. (2009), op. cit.

12 Tkacik, M. (2008), op. cit.
} 
kirumas. Vis dèlto pats autorius pripažista, kad tarp individualių autonomijos tipų (ypač tarp administracinès ir ịstatymų leidybos autonomijos) yra pilkoji zona, kurios niekaip negalima klasifikuoti ${ }^{13}$.

Kalbant apie ES ir jos siekius pasiekti norminiuose dokumentuose nenurodytą strateginę autonomiją (žr. ESPS), pagrindiniai užmojai yra orientuojami į funkcinę autonomiją, pirmiausia apimančią saugumo ir gynybos bei su ja tiesiogiai susijusią užsienio politikos sritị. Šiame kontekste strateginę autonomiją galima apibrèžti kaip politiką, kuria siekiama igyti ir išsaugoti didelio masto nepriklausomybę saugumo ir gynybos srityje, kuri suvokiama kaip strateginè. Jos tikslas - kuo labiau padidinti ES sprendimų prièmimo autonomiją saugumo ir gynybos srityje pagal tarptautinès sistemos struktūrą. Alexanderas Wendtas apibrèžè autonomiją „kaip valstybès - visuomenès komplekso gebėjimą kontroliuoti jos išteklių paskirstymą ir valdžios pasirinkimą", ne tik siekiant „išgyventi“, bet ir išsaugoti savo „laisvę"14.

Strateginę autonomiją galima apibrežti kaip ES gebèjimą užtikrinti savo saugumą sausumoje, ore, jūroje, kosmose ir kibernetinëje erdveje, taip siekiant demonstruoti galią ES ir už jos ribų tam, kad jos politiniai veiksmai būtų laisvi ir nepriklausomi nuo jokios išorinès ịtakos. Strateginę autonomiją taip pat būtų galima siaurai apibrèžti kaip gynybos technologijų ir pramonės autonomiją arba kaip visišką autonomiją, įskaitant operatyvinę nepriklausomybę ir teritorinę gynybą. Vis dèlto nederètų stengtis suprasti strateginès autonomijos vien tik kaip karinès, nors kariniai pajègumai politiškai yra svarbūs. Pagal apibrèžimą autonomijos terminas yra sąlyginis: ES turi būti autonominè kitų didžiųjų valstybių atžvilgiu. Apskritai ši koncepcija gali būti bendrai suvokiama kaip gebejjimas veikti ir bendradarbiauti su partneriais, kai tik tai įmanoma, išlaikant galimybę veikti nepriklausomai, kai tai reikalinga. Strateginès autonomijos esmè nèra savarankiškumas, o priemonès ir ịrankiai, skirti išorinès priklausomybès mažinimui tose srityse, kurios laikomos strateginemis ir kuriose priklausomybè gali būti siejama su autonomija, tuo pat metu daugiašaleje aplinkoje tęsiant bendradarbiavimą su partneriais. Europos strateginè autonomija turètų būti koncepcija, prieš nieką nenukreipta. Tai nèra transatlantinio bendradarbiavimo, ne paramos NATO, kaip kolektyvinès gynybos pagrindui, kvestionavimas, taip tik parodomas poreikis tapti svarbesniu ES sąjungininkų partneriu už Atlanto ir kituose forumuose prisideti prie saugumo pasaulyje palaikymo, ko ES ir siekia. Bendradarbiavimas gynybos srityje yra svarbus strateginès autonomijos elementas. Be bendradarbiavimo gynybos srityje strateginès autonomijos Europoje nebus.

\footnotetext{
${ }^{13}$ Ibidem, p. 401.

${ }^{14}$ Wendt, A. (1999), Social Theory of International Politics, Cambridge: Cambridge University Press, p. 98.
} 
Minètos aplinkybės leidžia daryti išvadą, kad ES strateginę autonomiją galima apibrèžti kaip diskursų ir strategijų rinkinį, nukreiptą ị veiksmų laisvès apsaugą, išnaudojant gynybos galimybes, siekiant užtikrinti ES valstybių narių saugumą. Taigi, pagrindinis tikslas yra sukurti arba išlaikyti pakankamą strateginę erdvę, taip siekiant kartu turèti pakankamai erdvès autonomijai (saugumo ir gynybos atžvilgiu) tam, kad liktų galimybe igyvendinant Europos priimtus sprendimus manevruoti.

\section{Dilemos dèl ES strateginès autonomijos saugumo ir gynybos srityje}

Nors terminas „strateginė autonomija“ gana dažnai vartojamas įvairiuose kontekstuose, susijusiuose su ES saugumu ir gynyba, jo reikšmè ir aiškinimas nèra aiškūs. Vieną iš kelių apibrèžimų pasiūlè Arunoday Bajpai. Jis nurodo, kad strategine autonomija reiškia „užsienio politikos poziciją, kai tauta išlaiko nepriklausomą požiūrị ir orientaciją užsienio reikalų atžvilgiu, sprendžiant klausimus, nulemiančius jos pagrindinius interesus “"15. Remiantis šiuo apibrěžimu, strateginè autonomija turètų būti vienas Europos tikslų, svarbesnis nei individualūs ES valstybių narių interesai, kad jos galètų užtikrinti saugumą. ES strateginę autonomiją galima igyvendinti daugeliu lygių ir daugelyje sričių. Plètojant minètąji apibrěžimą, derètų apsvarstyti galimybę ivertinti pagrindinius jo elementus, kurie yra „nepriklausomybe“ ir „pagrindiniai interesai“. Pirmasis reiškia, kad prireikus ES gali veikti savarankiškai. Kita vertus, paprastai antrasis suprantamas taip, kad tai gali būti valstybių narių interesų suma. Problema kyla dèl to, kad nacionaliniai interesai yra įvairialypiai ir ịvairūs. Šiuolaikineje Europos saugumo aplinkoje matomi Rytų Europos ir Pietų Europos šalių suvokiamų grèsmių skirtumai. Sutarimo stoka, sprendžiant dèl „pagrindinių interesų“, reiškia, kad strateginès autonomijos negalima apibrèžti per ES valstybių narių interesus. Dèl to būtų sunku prieiti prie bendros nuomonès, nes ES siekiai yra neabejotinai svarbesni. Sprendžiant šią dilemą, „pagrindinių interesų “ apibrèžimą galètų sudaryti ES visuotinès strategijos turinys, apimantis „bendrų interesų“ apibrěžimą, ̣̇ kurị ịeina: a) valstybių narių piliečiu saugumo skatinimas pagal vidaus ir užsienio veiksnius; b) klestejjimas, kuriam reikalinga atvira ir patikima tarptautiné ekonomikos sistema

\footnotetext{
${ }^{15}$ Bajpai, A. (2020), "What is meant by Strategic Autonomy with respect to India's foreign Policy?” Quora, Available at: https://www.quora.com/What-is-meant-by-Strategic-Autonomy-with-respect-to-Indiasforeign-Policy, (Accessed: 27 July 2020).
} 
ir nuolatinės galimybės naudotis visuotinėmis socialinėmis prekėmis, atsižvelgiant $\mathfrak{i}$ Europos ekonomiką ir nuolatinio gamtinių išteklių tiekimo poreikį; c) ES demokratijos patvarumo didinimas, pagarba jos normoms ir vertybems ir jų skatinimas; d) taisyklemis grịsta visuotinè tvarka, kurios pagrindas yra daugiašališkumo principas, skatinimas ${ }^{16}$.

ES gali apibrèžti savo strateginę autonomiją pagal tarptautinio bendradarbiavimo ir bendradarbiavimo su regioniniais partneriais galimybių poreikị, tuo pat metu išlaikant galimybę veikti savarankiškai, kai tai įmanoma, kur ir kai to reikia ${ }^{17}$. Dèl to tai yra taikoma Europos šaliu gebejjimui nusistatyti savo pačių prioritetus ir priimti nepriklausomus sprendimus dèl užsienio, saugumo ir gynybos politikos ir turèti lèšų, sudarančių galimybę igyvendinti apibrèžtus prioritetus ir sprendimus individualiai ar su partneriais. Dauguma ES strateginès autonomijos koncepcijos šalininkų argumentuoja, kad Europai derètų prisiimti visą atsakomybę už saugumą Europoje, kaip priemonę dèl neaiškios JAV pozicijos šiais klausimais. Tuo pat metu jie pabrèžia, jog tai nereiškia, kad aljansų ir bendradarbiavimo su partneriais už ES ribų atsisakoma, priešingai - didesnis ES įsitraukimas sustiprins transatlantinius santykius ir Europos saugumą tolesnejje aplinkoje. Savo ruožtu ES strateginès autonomijos kritikai kvestionuoja ES galimybes pasiekti strateginę autonomiją saugumo ir gynybos srityje ir įspejja dẻl santykių su JAV pablogèjimo (ypač gynybos pramonèje). Jie taip pat nerimauja dèl Prancūzijos požiūrio ị saugumą ir gynybą, kurio laikantis būtų visiškai atsisakoma partnerio iš už Atlanto dalyvavimo, sprendžiant su gynyba ir saugumu susijusius klausimus ${ }^{18}$.

Išsamaus ir nedviprasmiškai aiškinamo apibrèžimo stoka reiškia, kad ES valstybès narès skirtingai supranta strateginę autonomiją ir ji yra skirtingai aiškinama individualioje ES politikoje ${ }^{19}$. Saugumo ir gynybos srityje ji reiškia keturių sričių veiklą: politinę, institucinę, pajègumų ir pramonès ${ }^{20}$. Pirmoji sri-

\footnotetext{
${ }^{16}$ EEAS (2016), "Shared Vision, Common Action: A Stronger Europe. A Global Strategy for the European Union's Foreign And Security Policy”, Available at: https://eeas.europa.eu/archives/docs/top_stories/pdf/ eugs_review_web.pdf, (Accessed: 30 July 2020).

${ }^{17}$ Camporini, V., Hartley, K., Maulny, J.P., Zandee, D. (2017), "European Preference, Strategic Autonomy and European Defence Fund", Armament Industry European Research Group, Available at: https://www. clingendael.org/sites/default/files/2017-11/Ares-22-Report-Nov-2017.pdf, (Accessed: 30 July 2020).

${ }^{18}$ Drent, M. (2018), "European strategic autonomy: Going it alone?", Clingendael - the Netherlands Institute of International Relations, Available at: https://www.clingendael.org/sites/default/files/2018-08/PB_European_Strategic_Autonomy.pdf, (Accessed: 30 July 2020).

${ }^{19}$ Howorth, J. (2019), "Strategic Autonomy. Why It's Not About Europe Going it Alone", Wilfried Martens Centre for European Studies, Available at: https://www.martenscentre.eu/sites/default/files/publicationfiles/strategic-autonomy-europe.pdf, (Accessed: 30 July 2020).

${ }^{20}$ Varga, G. (2017), “Towards European Strategic Autonomy? Evaluating the New BSGP Initiatives", Institute for Foreign Affairs and Trade, Available at: https://kki.hu/assets/upload/07_KKI-Studies_BSGP_VargaG_20171003.pdf, (Accessed: 30 July 2020).
} 
tis, politiné autonomija, susijusi su vadovavimu ES, kalbant apie tai, kas gali vadovauti strateginès autonomijos pletrai ir koks yra ES siekių lygis šiuo atžvilgiu. Institucinė autonomija reiškia strateginès autonomijos iggvendinimui reikalingų struktūrų valdymo lankstumą. Savo ruožtu pajėgumai turètų apibūdinti realią galimybę naudotis kariniais, civiliniais, finansiniais, operatyviniais ir kitais ištekliais, siekiant patikimai igyvendinti prioritetus ir sprendimus strateginès autonomijos srityje. Pramonės autonomijos sritis reiškia technologinę bazę, kuri turètų teikti gynybos pajègumus, užtikrinančius ES strateginès autonomijos ịgyvendinimą. Keturių ramsčių remiamas strateginès autonomijos modelis reiškia, kad jo iggyvendinimas yra laipsniškas ir vystomas. ES gali palaipsniui didinti autonomiją, ir tikètina, kad kai kuriose srityse pavyks pasiekti daugiau nei kitose ${ }^{21}$.

Minètosios dilemos yra matomos ir ES valstybių narių diskusijose. ES

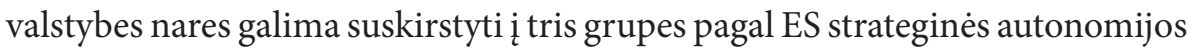
siekị saugumo ir gynybos srityje. Pirmoji tvirtai pasisako už jos igyvendinimą, ją pirmiausia sudaro Prancūzija, Vokietija, Italija ir Ispanija. Antroji šalių grupè yra neutrali (pvz., Baltijos šalys, Vengrija). Kita vertus, trečioji šalių grupé aiškiai ginčija strateginės autonomijos svarbą, kaip grèsmę NATO vaidmeniui ir transatlantiniams santykiams (pvz., Lenkija, Nyderlandai, Švedija, Danija). Prancūzija - didžiausia ES strateginès autonomijos šalininkè. Taip yra dèl to, kad strateginès autonomijos koncepcija yra viena pagrindinių jos gynybos politikos taisyklių, laikant ją jos suvereniteto ir gebejjimo visavertiškai atlikti tarptautinių ryšių funkcijas sąlyga. Taigi Prancūzija skatina savo strateginès autonomijos koncepcijos plètrą Europos lygiu. Prancūzijos poveikis yra akivaizdus, plètojant dabartinę Europos strateginio mąstymo koncepciją. Pagal ją, yra laikoma, kad strateginès autonomijos pagrindą sudaro du ramsčiai: aukšto lygio pramonès ir technologijų autonomija, iš vienos pusès, ir priemonés bei ištekliai, reikalingi operatyvinès autonomijos užtikrinimui, iš kitos pusès. Yra santykinis susijungimas, pristatant strateginę autonomiją kaip politinès autonomijos, operatyvinès autonomijos ir pramonès autonomijos derinį ${ }^{22}$. Vokietijoje - šalyje, kuri dažnai vertinama kaip pusiausvyra tarp transatlantinių ir Europos kraštutinumų, - egzistuoja gana įdomus Europos strateginès autono-

\footnotetext{
${ }^{21}$ Järvenpää, P., Major, C., Sakkov, S. (2019), "European Strategic Autonomy. Operationalising a Buzzword", International Centre for Defence and Security, Available at: https://icds.ee/wp-content/uploads/2019/10/ICDS_Report_European_Strategic_Autonomy_J\%C3\%A4rvenp\%C3\%A4\%C3\%A4_Major_Sakkov_October_2019.pdf, (Accessed: 30 July 2020).

${ }^{22}$ Brustlein, C. (2018), "European Strategic Autonomy: Balancing Ambition and Responsibility", Ifri, Available at: https://www.ifri.org/sites/default/files/atoms/files/brustlein_european_strategic_autonomy_2018. pdf, (Accessed: 20 October 2020).
} 
mijos suvokimas, kuriam ịtakos turi vokiečių ịsipareigojimas dèl Europos integracijos ir jų sudètinga karinès jègos naudojimo istorija. Vokiečių manymu, Europos strateginè autonomija daugeliu atžvilgiu priklauso nuo ES vienybès ir tvirtos politinés struktūros, kurią galima vertinti kaip išankstinę bet kokiu pajėgumų plètros ir pateikimo sąlygą. Dèl to tai yra platesnès Europos integracijos projekto dalis. Vokietijos nuomone, nepaisant tam tikro susitelkimo į Europą, ši BSGP plètros eiga neprieštarauja stiprios transatlantinès partnerystės palaikymui. Matomi teigiami pokyčiai ES saugumo ir gynybos politikoje yra ganètinai naudingi abiem šalims ${ }^{23}$.

Atsižvelgiant ị neutralių šalių, tokių kaip Baltijos šalys, balsus, jos palyginti laisvai gali formuluoti savo Europos strateginès autonomijos viziją taip, kaip tai būtų naudingiausia jų gynybos politikos interesams. Jas domintų platesnis tarpvalstybinis bendradarbiavimas gynybos pramonès srityje, integracija, konsolidacija ir investicijos, del ko jos taptų sudètine Europos gynybos pramonès bazès dalimi. Šiuo atžvilgiu ypatingai svarbūs yra Europos mechanizmai, kurie skatina kuo didesnio valstybių narių skaičiaus ịsitraukimą ir užtikrina vienodas sąlygas, ypač MVIt, kurios dominuoja Baltijos šalių pramonès tiekimo bazèje. Kita vertus, dèl tvirtos transatlantinès strateginès orientacijos jos atsargiai žiūri ị iniciatyvas, kurios gali pakenkti transatlantiniam bendradarbiavimui ir santykiams su JAV gynybos pramone. Dẻl Baltijos šalių dèmesio eksporto galimybių ir konkurencingumo didinimui bei jų susirūpinimo dèl tiekimo saugumo ir galimybès naudotis pažangiausiomis preciziškomis technologijomis tokiose srityse kaip kibernetinis saugumas jos, suprantama, yra vidutinio lygio Europos strateginès autonomijos, pagal kurią tokios aplinkybės yra laikomos abipuse pusiausvyra, šalininkès ${ }^{24}$.

Lenkija yra ES strateginei autonomijai prieštaraujančios šalies pavyzdys. Ji traktuoja šią koncepciją kaip būsimos NATO adaptacijos klausimą, atsiŽvelgdama ị didejjančią Rusijos grèsmę, o ne kaip ES, kaip strateginès veikejjos, likimą. Dèl to Lenkija parèmè ir, tikètina, toliau rems daugumą Europos iniciatyvų, skirtų turimų bendrų NATO gynybos įsipareigojimų vykdymui reikalingų pajėgumų fondui išplèsti. Dèl to Lenkijoje laikoma, kad transatlantinio bendradarbiavimo kontekste Europos strateginè autonomija blogèja. Siekiant užtikrinti tolesnị ir efektyvų JAV dalyvavimą, užtikrinant Europos saugumą, NATO sąjungininkai Europoje turi daugiau prisidèti prie gynybos išlaidų ir

\footnotetext{
${ }^{23}$ Arteaga, F., Jermalavicius, T., Marrone, A., Maulny, J-P., Terlikowski, M. (2016), "Appropriate Level Of European Strategic Autonomy", Report No. 8, Armament Industry European Research Group, Available at: https://icds.ee/wp-content/uploads/2016/ARES-Group-Report-Strategic-autonomy-November-2016.pdf, (Accessed: 20 October 2020).

${ }^{24}$ Ibidem.
} 
igyjamų pajejgumų. Europos gebejimas prisiimti didesnę savo gynybos naštos dalị bei stabilizuoti savo kaimynystę yra laikomas vienu svarbiausių veiksnių, lemsiančių transatlantinio bendradarbiavimo ir visos Europos saugumo ateitt̨ ${ }^{25}$.

Strateginé autonomija tapo pagrindine sąvoka pastaruoju metu vykstančiose diskusijose dèl BSGP ir ES dokumentuose. Vis dèlto jos konkreti reikšmė niekada oficialiai nebuvo apibrèžta, dèl to valstybių narių aiškinimo skirtumai yra akivaizdūs. Labiausiai paplitusiame apibrèžime minimas ES gebejjimas vykdyti sudètingas karines operacijas artimiausioje Europos aplinkoje. Dvi pagrindinès kliūtys, rodančios ES nesugebẻjimą pasiekti strateginę autonomiją, - politinis susiskaldymas ir karinis silpnumas. Pagrindinès kliūtys bendradarbiavimo saugumo ir gynybos srityje plètrai tarp valstybių narių pirmiausia yra susijusios su susirūpinimu dèl suvereniteto ir abipusio pasitikèjimo, techninemis, biurokratinemis ir finansinemis problemomis ir klausimais, susijusiais su gynybos pramone.

Europos šalys turètų siekti strateginès autonomijos saugumo ir gynybos srityje, įskaitant aiškiai apibrèžiamą terminologiją ir šios srities koncepcijas. Terminologijos aiškumo stoka gali lemti nesusipratimus sprendžiant su saugumu ir gynyba susijusius klausimus. ES ambicijos strateginès autonomijos kontekste taip pat turètų būti aiškiai apibrèžtos, derètų vengti nerealių ir prieštaringų idèjų, kurios skiriasi nuo diskusijų šiuo atžvilgiu pagrindo. Vienas iš pavyzdžių yra Europos kariuomenės idejja, kurią valstybès narès vertina prieštaringai. ES turètų dèti visas pastangas, siekdama išaiškinti strateginès autonomijos idejją pagrindiniams partneriams, ypač Jungtinėms Amerikos Valstijoms ${ }^{26}$. Tai pasiūlymas stiprinti saugumą ir gynybą transatlantiniu aspektu, suteikiant platesnes galimybes. Be to, tada nekyla problemų dèl NATO, o artimesnis ES ir NATO bendradarbiavimas visiems yra naudingas dèl saugumo ir gynybos ${ }^{27}$. Kompromiso paieška gynybos pajegumų plètros srityje ir jų naudojimas ateityje yra iššūkis, kuris ES strateginès autonomijos atžvilgiu turètų atspindèti šias sritis: a) bendrą siekių ir grèsmių suvokimo lygị; b) gynybos pajègumų plètros suderinimą; c) bendrus saugumo ir gynybos projektus; d) bendradarbiavimą su svarbiausiais partneriais.

\footnotetext{
${ }^{25}$ Ibidem.

${ }^{26}$ Thompson, J. (2019), "European Strategic Autonomy and the US”, Center for Security Studies (CSS) at ETH Zurich, Available at: https://doi.org/10.3929/ethz-b-000362178, (Accessed: 3 August 2020).

${ }^{27}$ Howorth, J. (2018), "Strategic autonomy and EU-NATO cooperation: threat or opportunity for transatlantic defence relations?”, Journal of European Integration, 40(5), pp. 523-537, Available at: https://doi.org/ 10.1080/07036337.2018.1512268, (Accessed: 3 August 2020).
} 


\section{Veiksniai, turintys itakos ES strateginei autonomijai saugumo ir gynybos srityje}

\subsection{Bendras siekių ir grèsmių suvokimo lygis}

Kalbant apie strateginę autonomiją, diskusiją derètų pradèti nuo esminių ES interesų apibréžimo, nustatant juos kaip reikiamą minimumą, būtiną Europos vertybių išsaugojimui. Dèl to svarbu apibrěžti siekių lygị ir identifikuoti grèsmes. Vargiai ịmanoma apibrèžti bendrą grèsmių ES saugumui suvokimą. Tai yra baimès, siejamos su individualių valstybių narių įvardintomis grèsmėmis, suma ${ }^{28}$. Šiame kontekste matomas susiskirstymas ị Rytų ir Pietų Europą: pirmuoju atveju, išdėstant faktus, vyrauja grèsmès, siejamos su Rusija, o antruoju atveju nerimaujama dèl nelegalios migracijos ir terorizmo. 2016 metais patvirtinta ES visuotinè strategija, apibrěžianti esminius ES interesus - piliečių saugumą, klestèjimą, demokratiją ir visuotinę isstatymais pagrịstą tvarką, - reprezentuoja didžiuli proveržĭ, apibrežiant Europos saugumo siekių lygị ir suvokimą. Pagal esminius ES interesus nustatyti penki išorinių veiksmų prioritetai: a) Europos Sąjungos saugumas; b) valstybių ir visuomenés atsparumas Rytuose ir Pietuose; c) integruotas požiūris ị konfliktus; d) regionų bendradarbiavimo tvarka; e) visuotinis valdymas XXI amžiuje ${ }^{29}$. Nors ESPS nèra pateikiama išsamios informacijos apie prioritetus, atrodo, kad orientavimasis ị ES ir jos piliečių saugumą bei demokratijos skatinimo funkcijos sumažinimas yra svarbus žingsnis, kurị reikëjo žengti kur kas anksčiau. ESPS turinys aiškiai rodo žemesnį Europos siekių lygị politine prasme, todèl jis yra labiau tikroviškas, ir tai atspindi investicijos, skatinančios tiesioginèje ES kaimynystëje esančių valstybių atsparumą, o ne didelę visiems skirtą transformacijų programą. Visas ESPS turinys patvirtina pagrindinį NATO vaidmeni, palaikant saugumą Europoje ir nurodant, kad kolektyvinès gynybos srityje NATO išlieka pagrindine struktūra daugumai ES narių.

\subsection{Gynybos pajėgumų plètros suderinimas}

Kitas klausimas, turintis reikšmingą įtaką ES strateginei autonomijai, apima suderinimo plètojant norimus saugumo ir gynybos pajègumus proble-

\footnotetext{
${ }^{28}$ Franke, U., Varma, T. (2019), "Independence play: Europe's pursuit of strategic autonomy", European Council on Foreign Relations, Available at: https://www.ecfr.eu/specials/scoreSMPGS/independence_play_ europes_pursuit_of_strategic_autonomy, (Accessed: 3 August 2020).

${ }^{29}$ EEAS (2016), op. cit.
} 
mas. Naujų ES gynybos pajègumų kūrimas bei esamų gerinimas ir didinimas yra vienas svarbiausių būsimos ES strateginès autonomijos užtikrinimo saugumo ir gynybos srityje elementų. Koordinuota ES valstybių narių pajègumų plètra yra vienas prioritetų, siekiant strateginès autonomijos. Kalbant apie veiksmus, kurių galima imtis, ypatingą dėmesi derètų skirti dviem iniciatyvoms: pajègumų plètojimo planui (PPP, angl. CDP) ir suderintai metinei peržiūrai gynybos srityje (SMPGS, angl. CARD).

PPP bus priemoné, siejanti kitas saugumo ir gynybos iniciatyvas, siekiant užtikrinti ilgalaikị karinių pajėgumų koordinavimą ir integravimą ES. Tai tiesiogiai lemia ESPS turinys, kai kalbama apie PPP funkcijų stiprinimą, valstybėms narèms plètojant tuos pajègumus, kurie atitinka ES politinius tikslus saugumo ir gynybos srityje. Dabartiniai pokyčiai, vykstantys Bendrijos saugumo ir gynybos politikos srityje, reiškia, kad PPP gali tapti ES gynybos pajègumų plètros kelrodžiu, atsižvelgiant ị grèsmes saugumui, patirti, pajègumų stoką, politinius ir pramonés prioritetus, technologinę plètrą ir ES visuotinių siekių lygi. Taigi PPP yra svarbi priemoné, siekiant strateginès ES autonomijos saugumo ir gynybos srityje $\mathrm{e}^{30}$.

SMPGS yra nauja priemoné, kurią naudojant siekiama susidaryti bendrą vaizdą apie dabartinę valstybių narių pajègumų padètį ir reguliariai tikrinti, kokiu mastu jos igyvendina ES pajègumų plètros plano prioritetus. Viena kliūčių, ribojančių valstybių narių bendradarbiavimą saugumo ir gynybos srityje, yra NATO ir ES gynybos planavimo ciklų skirtumas. Gynybos planavimo koordinavimo stoka ES tapo svarbiu veiksniu priimant sprendimą kurti naują iniciatyvą, kuri yra procesas, siekiant užtikrinti ES ir jos valstybėms narėms galimybę atlikti sistemingą ir išsamią turimų, plètojamų ir planuojamų karinių pajègumų peržiūrą. Pagal prielaidas SMPGS turètų padèti valstybèms narèms planuoti gynybą, siekiant užpildyti su ES operacijomis susijusias pajègumų spragas. SMPGS mechanizmas yra skirtas paramos teikimui valstybėms narèms, šioms siekiant igyti svarbiausius pajègumus, remiantis PPP numatytais prioritetais, taip pat sudaryti galimybę keistis informacija apie šalies modernizavimo planus ir galimą veiklos koordinavimą. Europos gynybos agentūra ịvardinta kaip pagrindinè institucija, vykdanti kasdienị proceso valdymą. Valstybės narès kasmet teiks EGA informaciją apie išlaidas gynybai, techninio modernizavimo planus ir tyrimų projektų pažangą. Jų analizė turètų sudaryti galimybę parengti rekomendacijas dèl ES valstybių narių ES prioritetų karinių

\footnotetext{
${ }^{30}$ Quain, C. (2019), "EU Strategic Autonomy: Filling the Gaps. A New Momentum for Common Security and Defence Policy", The Institute of International and European Affairs, Available at: https://docs.google. com/viewerng/viewer?url=https://www.iiea.com/wp-content/uploads/free-downloads-files/tempfiles/00213985000.pdf, (Accessed: 3 August 2020).
} 
pajègumų plètros srityje igyvendinimo, bendradarbiavimo gynybos srityje galimybių stiprinimo ir didesnio gynybos planavimo nuoseklumo pasiekimo ${ }^{31}$. Pirmoji bandomoji peržiūra prasidèjo $2017 \mathrm{~m}$. rudenị ir baigèsi $2018 \mathrm{~m}$. vasarą. Pirma išsami SMPGS turètų būti vykdoma 2019-2020 m., o jos išvados pristatytos EGA ataskaitoje. SMPGS procesas potencialiai gali pakeisti Europos mąstymą apie gynybos planavimą ir pajègumų stiprinimą. Tam bus reikalingas valstybių narių dalyvavimas aukštesniu lygiu nei paprastas pareiškimas. Savo ruožtu EGA, kaip viso mechanizmo sekretoriatas, turètų susitelkti i pajègumų spragų užpildymą, o tai bus ilgalaikis procesas.

\subsection{Bendri saugumo ir gynybos projektai}

Trečioji sritis susijusi su karinio bendradarbiavimo tarp ES valstybių narių stiprinimu. Toks bendradarbiavimas jau vyko, net jei tai buvo informacijos kaupimo ir dalijimosi ja iniciatyvos dalis, tačiau ateityje tai bus nuolatinis struktūrizuotas bendradarbiavimas (NSB, angl. PESCO), kuris gali pasiteisinti kaip perspektyvi iniciatyva, sudaranti ES galimybę naudotis konkrečiais kariniais pajëgumais.

NSB mechanizmas buvo sukurtas pagal Lisabonos sutartį ir gali tapti vienu svarbiausių ES naujosios Europos saugumo ir gynybos architektūros elemen$\mathrm{tuc}^{32}$. Dèl sutartyse numatytų NSB suteikiamų igaliojimų jis pasižymi ilgaamžiškumu, kas užtikrina realų valstybių narių bendradarbiavimą. Pagrindinis NSB privalumas yra jo ịpareigojantis pobūdis, ypač atsižvelgiant ị daugybę ankstesnių ES ir NATO priklausančių valstybių deklaracijų. Susidarius situacijai, kai valstybẻ nusprendžia dalyvauti atitinkamame NSB projekte, ji įsipareigoja ji vykdyti priimdama vadinamajj nacionalinị igyvendinimo planą, kurio igyvendinimą kasmet stebės naujai sukurtas EGA, Europos išorès veiksmų tarnybos ir ES karinio štabo remiamas NSB sekretoriatas, kuris yra pavaldus ES vyriausiajam igaliotiniui užsienio reikalams ir saugumo politikai ${ }^{33}$. Projekto igyvendinimo metu šalys atnaujins savo igyvendinimo planus, o kiekvieno etapo pabaigoje (t. y. 2021 ir 2025 m.) yra numatoma strateginè peržiūra dẻl valstybès ịsipareigojimų vykdymo pažangos bei galimos kito etapo pradžios arba deklaracijos peržiūros.

\footnotetext{
${ }^{31}$ Mazurek, K. (2018), "European offensive in defense sphere - EDF, PESCO and CARD," Casimir Pulaski Foundation, Available at: https://pulaski.pl/wp-content/uploads/2018/11/European_offensive_in_defense_ sphere_EEDF_PESCO_and_CARD_PL.pdf, (Accessed: 3 August 2020).

${ }^{32}$ Biscop, S. (2018), "European Defence: Give PESCO a Chance", Survival, 60(3), pp. 161-180, Available at: https://doi.org/10.1080/00396338.2018.1470771, (Accessed: 7 August 2020).

${ }^{33}$ Gotkowska, J. (2018), “The trouble with PESCO. The mirages of European defence”, Centre for Eastern Studies, Available at: https://www.osw.waw.pl/sites/default/files/pw_69_pesco_ang_net.pdf, (Accessed: 7 August 2020).
} 
Vadovavimo bendroms misijoms gerinimo srityje, ypač dèl krizių valdymo, buvo ịsteigtas Karinių misijų planavimo ir vykdymo centro (KMPVC, angl. MPCC) padalinys, kurio tikslas yra gerinti ES krizių valdymo struktūrą. KMPVC veiks ES kariniame štabe kaip Europos išorès veiksmų tarnybos dalis ir bus atsakingas už Malyje, Somalyje ir Centrinès Afrikos Respublikoje vykdomų nuolatinių mokymų operacijų koordinavimą. Pagrindinis jo uždavinys bus karinių misijų be vykdomojo igaliojimo operatyvinis planavimas ir vykdymas, taip pat ES pajègų kūrimas, mobilizavimas, palaikymas ir atkūrimas. Taikant šį metodą, misijos personalas bus sutelkiamas konkrečioms Briuselio remiamoms operacijoms vietoje ${ }^{34}$.

\subsection{Bendradarbiavimas su svarbiausiu partneriu - NATO}

Draugiškesnè NATO ir ES santykių koncepcija išsirutuliojo dèl būtinybès, nes abi organizacijos susiduria su naujais iššǔkiais, siekdamos užtikrinti valstybių narių saugumą ${ }^{35}$. Rytinèje puseje partneriai turi imtis svarbių ịsipareigojimų, siekdami užtikrinti rytinio NATO šono teritorinị vientisumą. Iš vakarų Jungtinès Amerikos Valstijos ragina iš naujo derètis dèl naštos pasidalijimo NATO. Pietinèje pusejje dẻl nuolatinių problemų kyla dažnos krizès, kurias sprendžiant reikalinga ir ekonomine, ir institucinè intervencija, partnerystè ir didžiulès atkūrimo pastangos. Be didesnio pajègų ịsitraukimo ir konkurencijos kaimynysteje, Europa taip pat privalo pasiruošti reaguoti $\mathfrak{i}$ jos piliečiams nerimą dèl saugumo keliančius dalykus ${ }^{36}$. Pagrindinès sritys apima apsaugą nuo terorizmo, kibernetines atakas, nekontroliuojamą migraciją ir hibridini kišimąsi ị demokratinius procesus. Kadangi ankstesnè prabanga - galimybė atitinkamu metu spręsti vieną problemą vienoje vietoje - tapo istorija, aišku, kad Europos saugumui reikia bendrų ES ir NATO pastangų ir išteklių, jos turi bendradarbiauti tarpusavyje tam, kad ịveiktų daugialypius vidinius ir išorinius iššūkius ${ }^{37}$.

\footnotetext{
${ }^{34}$ EEAS (2018, November), “The Military Planning and Conduct Capability (MPCC)”, Available at: https:// eeas.europa.eu/sites/eeas/files/MPCC_factsheet_november_2018.pdf, (Accessed: 7 August 2020).

${ }^{35}$ Howorth, J. (2017), "EU-NATO cooperation: the key to Europe's security future", European Security, 26(3), pp. 454-459, Available at: https://doi.org/10.1080/09662839.2017.1352584, (Accessed: 7 August 2020).

${ }^{36}$ Biscop, S. (2019), "Fighting For Europe. European Strategic Autonomy and the Use of Force", Egmont - Royal Institute for International Relations, Available at: http://www.egmontinstitute.be/content/ uploads/2019/01/EP103.pdf?type=pdf, (Accessed: 7 August 2020).

${ }^{37}$ Brustlein, C., (ed.), (2019), "Mutual Reinforcement. CDSP and NATO in the Face of Rising Challenges", Ifri, Available at: https://www.ifri.org/sites/default/files/atoms/files/fs93_brustlein_ed_mutual_reinforcement_2019.pdf, (Accessed: 11 August 2020).
} 
Ateinančiais metais net ir plataus užmojo ES reformos ir iniciatyvos pagal BSGP negalès pakeisti NATO; Europos lyderiai turi žinoti apie besikeičiančius JAV geopolitinius prioritetus. Šis pokytis nepriklauso nuo pastarujų JAV administracijų pareiškimų ar politikos, ir tai yra ilgalaikės tendencijos dalis. Nors JAV tęs karinị dalyvavimą Europoje, jos sieks didinti Europos sąjungininkams tenkančią naštą. Jų i̇sipareigojimų Europos saugumo atžvilgiu mažinimas nevyks kaip staigus ir radikalus politikos pokytis, bet kaip palaipsnio Aljanso susitarimų ir JAV įsipareigojimų pakeitimo dalis. Dèl šių priežasčių ES narėms nederètų skubinti JAV pasitraukimo proceso, tačiau jos turètų tam pasiruošti. Saugumo ir gynybos srityje tai reiškia susitelkimą ị realių karinių pajègumų plètojimą, kuriam reikia kur kas daugiau laiko nei susitarimų sudarymui institucijų lygmeniu.

Pristatytų iniciatyvų tikslas - ES pajègumų saugumo ir gynybos srityje stiprinimas, siekiant strateginès autonomijos. Bendras saugumo ir gynybos strateginès autonomijos ir su ja susijusių priemonių ES tikslas - galiausiai pertvarkyti, suderinti, sutelkti ir pasidalyti Europos pajėgumus, siekiant išvengti jų dubliavimo. Sutelkimas ir pasidalijimas reiškia ne tik bendradarbiavimą, bet ir integraciją. Kaip alternatyvą paprastam bendradarbiavimui saugumo ir gynybos srityje europiečiai steigia vieną instituciją, vieną pajègumų fondą, kuriuo galès naudotis visi. Pagrindinis rezultatas turètų būti padidintas Europos gynybos efektyvumas tam, kad Europa galètų pasiekti toki pat ekonominio efektyvumo lygi kaip ir jos svarbiausi partneriai, tokie kaip JAV. Vis dar yra sunkumų, siejamų su integruotos Europos gynybos struktūra, įskaitant skirtingus požiūrius dèl ES ir NATO santykių ir pastebejjimą, kad gynybos integracija gali prieštarauti nacionalinio suvereniteto principui. Nepaisant to, strateginès autonomijos ir pastebimos ịtakos pasaulio arenoje tikslą galima sèkmingai pasiekti tik tada, jei ES gynybos integracija ir toliau žengs i priekį.

\section{Išvados}

Remiantis čia aptartomis aplinkybėmis dèl ES strateginès autonomijos koncepcijos saugumo ir gynybos srityje, galima padaryti kelias išvadas. Pirma, gynybos iniciatyvų pradžia didina tikimybę, kad ateityje ES pavyks pasiekti strateginę autonomiją saugumo ir gynybos srityje. Šioje srityje svarbią funkciją atliks Europos Komisija, kuri turètų stebèti jų igyvendinimą ir plètrą. Ivairių finansavimo šaltinių suteikimas padidins numatomų gynybos projektų igyvendinimo tikimybę, taip sẻkmingai siekiant strateginès autonomijos tikslų. Pirmieji rezultatai tikriausiai bus pasiekti per kitus kelerius metus (tam gali prireikti net iki dešimtmečio). 
Antra, sutarimo stoka tarp ES valstybių narių dèl strateginės autonomijos koncepcijos suvokimo nėra palanki aplinkybè, kalbant apie jos siekių lygio pastovumą, įskaitant jos tikslus ir prioritetus. Valstybès narès ir ES institucijos ir toliau propaguos skirtingas koncepcijas, kurios atspindi jų pačių vizijas bendradarbiavimo gynybos srityje. Toks faktų išdèstymas gali lemti strateginès autonomijos idejos miglotumą. Svarbu tai, kad strateginès autonomijos koncepcija taip pat priklausys nuo išorinių veiksnių. Perrinkus Donaldą Trumpą Jungtinių Amerikos Valstijų prezidentu, tikètina, padidès susidomėjimas strategine autonomija pagal Prancūzijos idèją, o tai iš esmès reiškia visišką nepriklausomybę $e^{38}$. Tačiau tikètina, kad kito kandidato pergalè bus palanki transatlantiniais ryšiais pagrịstos strateginès autonomijos vizijai, ypač saugumo ir gynybos srityje, plètoti. Taigi transatlantinio dialogo pobūdis po 2020 m. Jungtinių Amerikos Valstijų prezidento rinkimų turès ypatingą ịtaką ES gynybos politikai, įskaitant jos pramonès sritị. Savo ruožtu saugumo rytiniuose ir pietiniuose flanguose plètra priklausys nuo grèsmių suvokimo Europoje, ir dèl to ES gali būti priversta atlikti pakeitimus, kurie turès įtakos strateginès autonomijos suvokimui ${ }^{39}$. Dėl minètų priežasčių ES narėms nederètų sudaryti situacijų, susijusių su Jungtinių Amerikos Valstijų pasitraukimu iš Europos gynybos, tačiau tuo pat metu joms reikètų tam pasiruošti ${ }^{40}$. BSGP srityje tai reiškia susitelkimą i realių karinių pajėgumų plètrą, kuri trunka kur kas ilgiau nei susitarimų sudarymas institucijų lygmeniu.

Trečia, ES narès yra suinteresuotos stipresniais Europos gynybos pajègumais ir vieningesne Europos saugumo politika. Vien tik patikimų karinių pajègų turejimas pagerins ES geopolitinę padètị derybose tarptautinèje arenoje tiek didžiųjų valstybių, tiek mažų ir silpnų priešininkų atžvilgiu. Europos pranašumai, siekiant strateginès autonomijos, yra jos ekonominè stiprybė ir bendroji rinka. Tarptautiniu mastu ES jau yra vertinama kaip strateginè veikèja reguliavimo, prekybos, konkurencijos ir duomenų apsaugos klausimais. ES valstybėms narèms ji suteikia Europos konkurencingumo gynybos ir palaikymo sistemą. Saugumo ir gynybos srityje PPP, SMPGS, NSB ir EDF iniciatyvos gali tapti norimų ES gynybos pajègumų igijimo ir plètros pagrindu.

\footnotetext{
${ }^{38}$ Smith, M.E. (2018), “Transatlantic security relations since European security strategy: what role for ES in its pursuit of strategic autonomy?”, Journal of European Integration, 40(5), pp. 605-620, Available at: https://doi.org/10.1080/07036337.2018.1488840, (Accessed: 11 August 2020).

${ }^{39}$ Haugevik, K., Rieker, P. (2017), "Autonomy or integration? Small state responses to a changing European security landscape", Global Affairs, 3(3), pp. 211-221, Available at: https://doi.org/10.1080/23340460.2017.1 377625, (Accessed: 11 August 2020).

${ }^{40}$ Fiott, D. (2018), “Strategic autonomy: towards 'European sovereignty' in defence?", European Union Institute for Security Studies (EUISS), Available at: https://www.iss.europa.eu/sites/default/files/EUISSFiles/ Brief\%2012_Strategic\%20Autonomy.pdf, (Accessed: 11 August 2020).
} 
Apibendrinant galima pasakyti, kad ES eina ilgu strateginès autonomijos saugumo ir gynybos srityje siekio keliu. Jai nereikia ir nereikètų to daryti savarankiškai. Realių gynybos galimybių plètojimas turi būti vykdomas gerbiant valstybių narių suverenitetą ir kartu su svarbiausiais partneriais, ypač NATO. Šiame kontekste autonomija turètų reikšti galimybę veikti nepriklausomai ir apimti bendradarbiavimą, ji neturètų peraugti ị izoliaciją ar juo labiau lemti ES valstybių narių susiskaldymą.

2020 m. rugpjūtis 